\title{
Dry matter accumulation and seasonal partitioning in mature Opuntia ficus-indica (L.) Mill. fruiting trees
}

\author{
Giorgia Liguori, Paolo Inglese, Giuseppe Sortino, Guglielmo Inglese \\ Dipartimento di Scienze Agrarie e Forestali, Università di Palermo, Italy
}

\begin{abstract}
Aim of this study was to understand the allocation of biomass into different canopy and root components and to measure the stem area index and its partitioning by cladode functionality (age), for fruiting Opuntia ficus-indica (OFI) Gialla trees, spaced $6 \times 5 \mathrm{~m}$ apart and trained to a globe. The net primary productivity (NPP), calculated taking into account dry weight gain for above-ground vegetative components of OFI trees was $3.6 \mathrm{t} \mathrm{C} \mathrm{ha}^{-1}$. Including the fruit component and $1^{\text {st }}$ flush current-year cladodes, NPP of above-ground components becomes $12 \mathrm{t} \mathrm{ha}^{-1}$, equivalent to $5.4 \mathrm{t} \mathrm{C} \mathrm{ha}^{-1}$. Current-year cladodes were the highest $\mathrm{C}$ sink (49\% of total annual $\mathrm{C}$ fixed in the canopy), secondary growth accounted for $22 \%$ of $\mathrm{C}$ fixation and the fruit component for $29 \%$. This study demonstrated that OFI trees, grown in a commercial fruit orchard, couple high productivity, in terms of fruit yield and harvest index, with relevant $\mathrm{C}$ fixed in the canopy.
\end{abstract}

\section{Introduction}

Opuntia ficus-indica (OFI) can have an annual dry matter productivity that exceeds that of nearly all cultivated $\mathrm{C}_{3}$ and $\mathrm{C}_{4}$ species. For instance, a productivity of $47 \mathrm{t}$ dry weight (dw) ha ${ }^{-1} \mathrm{yr}^{-1}$ of cladodes (99\%) and fruit (1\%) has been predicted for high density plantings (24 plants $\mathrm{m}^{-2}$ ), while a productivity of nearly $15 \mathrm{t} \mathrm{ha}^{-1}$ was measured for lower spacing $\left(0.24\right.$ plants $\left.\mathrm{m}^{-2}\right)$, resulting in a lower vegetative $v s$ reproductive growth, with early fruit cropping and an alternate bearing

Correspondence: Paolo Inglese, Dipartimento di Scienze Agrarie e Forestali, Università di Palermo, viale delle Scienze 11, 90128 Palermo, Italy.

E-mail: paolo.inglese@unipa.it

Key words: carbon allocation, stem area index, productivity.

Received for publication: 17 June 2013.

Revision received: 28 November 2013.

Accepted for publication: 28 January 2014.

(C) Copyright G. Liguori et al., 2014

Licensee PAGEPress, Italy

Italian Journal of Agronomy 2014; 9:537

doi:10.4081/ija.2014.537

This article is distributed under the terms of the Creative Commons Attribution Noncommercial License (by-nc 3.0) which permits any noncommercial use, distribution, and reproduction in any medium, provided the original author(s) and source are credited. behavior (Garcia de Cortazar and Nobel, 1992). Absolute growth rate for cladode and fruits can achieve 0.12 day $^{-1}$ and 0.16 day $^{-1}$ respectively. The fruit component (harvest index=HI) has been not systematically studied in OFI, though Inglese et al. (1999) measured, in a commercial orchard $\mathrm{HI}$ of $34 \%$ and $46 \%$ respectively for the spring and the summer flush that results from the removal of the spring flush of flowers and cladodes. Garcia de Cortazar and Nobel (1992) showed that yearly variations in cladode $v s$ fruit dry matter allocation also depend on planting densities. An increase of dry matter allocated to the fruit was accompanied by a reduction in cladode count and dry weight accumulation. Light interception, $\mathrm{CO}_{2}$ uptake and, then, plant productivity depend on canopy architecture and stem area (both sides of the cladode) index per ground area (SAI), that is the equivalent to the leaf area index (Nobel, 1988). Despite of their importance, SAI values for OFI orchards have been poorly investigated. Maximum dry weight $\mathrm{ha}^{-1} \mathrm{yr}^{-1}$ productivity has been predicted for a SAI of 4 to 5 , while for a $\mathrm{SAI}<3$, the total net $\mathrm{CO}_{2}$ uptake is about linear with SAI (Nobel, 1988). These calculations include all cladodes and do not take into account that single cladode contribution to $\mathrm{CO}_{2}$ uptake changes with cladode age (Nobel, 1988), and, also, that optimal SAI definition must include fruit quality, which also depend on PAR interception by mother cladodes (Inglese et al., 1999).

The study reported herein was designed to help understand the allocation of biomass into different canopy and root components, also in relation to fruit production and to measure SAI and its partitioning by cladode age, for fruiting OFI trees.

\section{Materials and methods}

The study was conducted on an experimental field near Roccapalumba $\left(37^{\circ} 48^{\prime} \mathrm{N} ; 13^{\circ} 38^{\prime} \mathrm{E} ; 350 \mathrm{~m}\right.$ asl), western Sicily, Italy, from May to November 2010. The semi-arid climate is characterized by a mean annual precipitation of $600 \mathrm{~mm}$. A 2.5 ha cactus pear orchard with cultivars Gialla (90\%), Rossa (8\%), and Bianca (2\%) was selected for the experiment. Ten-year-old trees were trained to a globe shape. Trees (maximum height of $3 \mathrm{~m}$ ) were spaced $5 \mathrm{~m}$ within the row and $6 \mathrm{~m}$ between rows, with 333 plants ha ${ }^{-1}$. Rows were oriented North-South. The annual marketable production was about $20 \mathrm{t} \mathrm{ha}^{-1}$ using the so-called practice scozzolatura, which means that, in June, the first flush of cladodes and flowers are removed to promote a return bloom and a later fructification (Barbera et al., 1991).

According to the United States Department of Agriculture (USDA) classification (SCS, 1982), the soil at the experimental field has a clayloam texture with $40 \%$ sand, $38 \%$ clay, and $22 \%$ silt. Volumetric soil water content is about $40 \%$ at field capacity. The irrigation system is made by four on-line labyrinth sprayers per plant and a discharge rate of $40 \mathrm{I} \mathrm{h}^{-1}$ per sprayer at a pressure of $150 \mathrm{kPa}$. During the irrigation period, from June throughout September 2010, a total of $150 \mathrm{~mm}$ of water was distributed, with an irrigation frequency ranging from 4 days to 1 week. 
The experiment was conducted on 6 trees selected within the orchard.

The annual above-ground growth of the trees was represented by the new flush of cladodes, flowers and fruit, plus the increase of dry matter in the elder cladodes. In 2010 all removed young cladodes and flowers were weighed to obtain their fresh mass. A ventilated oven at $60^{\circ} \mathrm{C}(\mathrm{M}-$ 250-VF, MPM Instruments srl, Bernareggio Monza e della Brianza, Italy) was used to dry the trees components until constant weight, for dry mass determination. Three weeks after the $2^{\text {nd }}$ bloom, fruits of the fruiting trees were thinned to leave no more than 6 fruits per cladode; thinned fruit were counted and measured in terms of fresh and dry weight. At commercial maturity (November 2010), fruit were harvested to measure yield per tree (kg) and then counted; current-year cladode produced by each tree were also removed from the tree and, then counted and weighed for fresh mass determination. Samples made by 50 current-year cladodes and fruit, collected by each of the six trees, were individually weighed and dried at $60^{\circ} \mathrm{C}$ in a ventilated oven to constant weight, for dry mass determination. To determine fresh and dry weight accumulation during the season of 1-year, 2-year, 3-year and 4-yearsold cladodes, their fresh and dry weight were measured from cork borer (1.4 $\mathrm{cm}$ in diameter) samples taken at the beginning (May) and the end (November) on 25 cladodes per age.

At the end of the season, to quantify the overall biomass partitioning, trees were sampled destructively and fractioned into canopy and root components. Canopy components, beside fruit and current-year cladodes, were 1-year-old cladode, two-year-old cladode, three-year-old cladodes and elder suberised cladodes; root components were fractioned into main root stem, primary and secondary roots. All cladodes were measured in terms of fresh weight, thickness, maximum length and width. All cladodes and roots subsamples were counted, weighed and then dried in a ventilated oven at $60^{\circ} \mathrm{C}$ to constant mass to determine their dry mass and to calculate the dry matter accumulated in the whole tree.

Moreover, to determine both photosynthetic and non-photosynthetic surface within the trees, cladode surface area (both sides) was calculated from the regression $\mathrm{SA}=0.8571(\mathrm{DL} * \mathrm{DT})+0.3652\left(\mathrm{R}^{2}=0.962\right)$, where $\mathrm{SA}$ is the surface area of the cladode, DL and DT are respectively cladode height and width $(\mathrm{cm})$. The regression was obtained from a sample of 150 cladodes whose length, width and thickness were measured and leaf area determined from paper silhouettes, with a leaf area meter (Windias, Delta-T Devices Ltd., Cambridge, UK). SAI per plant $\left(\mathrm{SAI}_{\text {orchard }}=\right.$ both sides of the cladode per ground area allotted to the tree; $\mathrm{SAI}_{\text {tree }}=\mathrm{SAI}$ : both sides of the cladode per ground area covered by the tree, $19.62 \mathrm{~m}^{2}$ ) and dry matter production per unit cladode area were then calculated, considering cladode age. Data of canopy surface area, sorted by cladode age, were submitted to ANOVA and means were separated with Tukey's test at $P \leq 0.05$.

\section{Results}

Annual above-ground productivity, in terms of dry weight gained per tree, is reported in Table 1. In 2010 the amount of dry matter fixed in the canopy (secondary growth and current-year cladodes) was $7.9 \mathrm{t}$ ha $^{-1}$; net primary productivity (NPP), calculated taking into account dry weight gain for above-ground vegetative components of OFI trees and a $\mathrm{C}$ percentage of $45 \%$ (Inglese et al., 2012), was $3.6 \mathrm{t} \mathrm{C}^{-1}$. Including flowers and current-year cladodes of the $1^{\text {st }}$ flush and thinned fruit of the $2^{\text {nd }}$ flush, NPP of above ground components becomes $12 \mathrm{t} \mathrm{ha}^{-1}$, equivalent to $5.4 \mathrm{t} \mathrm{C} \mathrm{ha}{ }^{-1}$. The calculated harvest index (HI=annual dry matter allocated to the fruit component) was about $29 \%$, considering both $1^{\text {st }}$ and $2^{\text {nd }}$ flush, or $26 \%$ if we only consider the reproductive and vegetative growth of the second flush.

The development of current-year cladodes accounted for almost $70 \%$ of vegetative annual growth so that the other $30 \%$ was accumulated by elder cladodes. In order to perform solid scaffold throughout the years more than $23 \%$ of what is annually gained is stored in those cladodes older than 1year (Table 1).

Crop yield (fresh weight) in 2010 was $20 \mathrm{t} \mathrm{ha}^{-1}$, and average fruit weight was $130.6 \pm 4.5 \mathrm{~g}$, with a total soluble solid content of $13.1 \pm$ $0.24^{\circ}$ Brix.

The dry mass of fruit yield per unit ground area was $0.27 \mathrm{~kg} \mathrm{~m}^{-2}$. If we consider flowers removed to get a second bloom and fruit thinned few weeks after fruit set, the amount of dry mass diverted to reproductive growth was $0.35 \mathrm{~kg} \mathrm{~m}^{-2}$ ground area. Vegetative annual growth of canopy components was $0.86 \mathrm{~kg} \mathrm{~m}^{-2}$ ground area.

Dry matter accumulation and partitioning per canopy component is shown in Table 2 . Tree dry weight was $15 \%$ of fresh weight, excluding the fruit component. The trunk showed the highest values in terms of fresh and dry weight among the above-ground components, due to the great accumulation of lignin and the loss of the water storage activity of parenchyma by aged cladodes.

Roots accounted for $6.8 \%$ of tree fresh weight and $17.5 \%$ of tree dry matter. Destructively sampling analysis detected flashy primary roots ( $28 \% \mathrm{dw}$ ) spread by the main root stem, and secondary roots with almost $40 \%$ of dry matter. Moreover, main root stem and primary roots accounted for more than $90 \%$ of the whole below-ground dry mass of the trees (data not shown).

Specific dry weight and surface area of the trees is reported in Table 3. The seasonal dry matter (fruit, current-year cladodes, secondary growth of older canopy components) per unit of surface area of photosynthetically most active cladodes area (current-year cladodes + 1-year-

Table 1. Number, and annual fresh and dry gain $( \pm \mathrm{SE})$ of above-ground canopy components in 10-year-old Opuntia ficus-indica trees $(\mathbf{n}=6)$ cv. Gialla, trained to a globe.

\begin{tabular}{|c|c|c|c|c|}
\hline & Number & $\begin{array}{l}\text { Fresh weight } \\
\text { (kg) }\end{array}$ & $\begin{array}{l}\text { Dry weight } \\
\text { (kg) }\end{array}$ & $\begin{array}{c}\text { Dry mass } \\
(\%)\end{array}$ \\
\hline $1^{\text {st }}$ flush current-year cladode removed & $80 \pm 14.2$ & $9.5 \pm 0.3$ & $2.0 \pm 0.06$ & 5.5 \\
\hline Current-year cladodes & $224 \pm 17.1$ & $217.7 \pm 14.3$ & $15.8 \pm 1.1$ & 43.6 \\
\hline $1^{\text {st }}$ flush flowers removed & $1600 \pm 93.0$ & $32.1 \pm 0.77$ & $2.1 \pm 0.07$ & 5.7 \\
\hline $2^{\text {nd }}$ flush thinned fruit & $180 \pm 13.1$ & $4.5 \pm 0.4$ & $0.4 \pm 0.02$ & 1.1 \\
\hline Harvested fruit & $458 \pm 35.3$ & $59.8 \pm 1.4$ & $7.9 \pm 0.2$ & 21.8 \\
\hline Dry weight annual gain (1-year-old cladodes) & $219 \pm 12.5$ & - & $2.0 \pm 0.07$ & 5.5 \\
\hline Dry weight annual gain ( $\geq 2$-year-old cladodes)* & $347 \pm 25.0$ & - & $6.0 \pm 0.2$ & 16.6 \\
\hline Total & & & $36.2 \pm 1.7$ & 100 \\
\hline
\end{tabular}

*Include also the non-photosynthetic cladodes (scaffold). 
old cladodes + 2-year-old cladodes) was $0.48 \mathrm{~kg} \mathrm{dw} \mathrm{m}^{-2}\left(0.11 \mathrm{~kg} \mathrm{dw} \mathrm{m}^{-2}\right.$ for the fruit component). The dry weight per unit surface area of 2years-old cladodes was twice as much than in current year ones and $30 \%$ higher than in 1-year-old ones.

A percentage of 64 of total surface area of the trees was made by current-year, 1-year-old and 2-year-old cladodes (Figure 1), which are the most active cladodes in terms of photosynthetic efficiency, with a total surface area of $77 \pm 4.0 \mathrm{~m}^{2}$ (Table 3 ).

$\mathrm{SAI}_{\text {tree }}$ and $\mathrm{SAI}_{\text {orchard }}$ were respectively 6.2 and 4.1. (Figure 2). $\mathrm{SAI}_{\text {tree }}$ was 4.0 considering just current-year, 1-year-old and 2-year-old cladodes, thus only $36 \%$ of solar radiation is intercepted by the less photosynthetically efficient cladode.

\section{Discussion}

Above-ground NPP values of 5.1, 4.7, and $5.5 \mathrm{t} \mathrm{C} \mathrm{ha}^{-1}$ have been recently measured for peach, apple, and citrus orchards, respectively (Tagliavini et al., 2008). Seasonal C fixation by single tree canopy, vegetative, components was $10.8 \mathrm{~kg} \mathrm{C}$ tree ${ }^{-1}$, which is very similar to 10.7 $\mathrm{kg} \mathrm{C}$ tree $^{-1}$ reported for 14-year-old Tarocco orange trees spaced $4.5 \times 4.5$ $\mathrm{m}$ apart, and twice as much as annual C fixed in 12-year-old New Hall orange trees spaced $4.0 \times 2.5 \mathrm{~m}$ apart (Liguori et al., 2009). Current-year cladodes were the highest $\mathrm{C}$ sink (49\% of total annual C fixed in the canopy), while secondary growth accounted for $22 \%$ of $\mathrm{C}$ fixation and the fruit for $29 \%$. In other words, even in a year of particularly high production, the orchard was able to divert most of its $\mathrm{C}$ to the new vegetation and the secondary growth of vegetative components. Acevedo et al. (1983) measured a cladode dry mass production of $1 \mathrm{~kg} \mathrm{~m}^{-2}$ ground area and $0.3 \mathrm{~kg}_{\text {fruit m}}{ }^{-2}$ year-1. Recently Pinos-Rodríguez et al. (2010) reported a dry mass production of $1.39 \mathrm{~kg} \mathrm{~m}^{-2}$, for OFI grown to produce fresh biomass for cattle use. Nobel (1988) reports maximum values of $2 \mathrm{~kg}$ dry mass $\mathrm{m}^{-2}$ ground area year-1. Working in a commercial orchard for fruit production we found similar values $\left(1.2 \mathrm{~kg} \mathrm{~m}^{-2}\right.$ ground area considering the first and the second flush of fruits and cladodes). At the end of the first season of growth, current-year cladodes reach almost entirely the surface area of 1-year-old cladodes, but only $65 \%$ of their dry weight. During the second year of growth they show a marginal increase in terms of surface area, but a significant accumulation of dry weight $(+30 \%)$. From then onwards, cladodes marginally develop in term of surface area, but continue to accumulate dry weight. Scaffold cladodes have a twice as high specific dry weight than 1-year-old cladodes. Maximum productivity ( $>30 \mathrm{t}$ of total biomass dry weight ha ${ }^{-1}$ year $^{-1}$ ) has been predicted (Nobel, 1988) for a SAI of 4 to 6 , with 20,000 and 6000 plants ha ${ }^{-1}$. Though our commercial plantations for fruit production had a much lower plant density (333 trees ha ${ }^{-1}$ ), we measured very similar values than Nobel (1988), but for a much lower total biomass (dry weight) and a commercial fruit weight. However, the photosynthetically active canopy components (Liguori et al., 2013) account for $60 \%$ of canopy surface, with $\mathrm{SAI}_{\text {orchard }}(2.6)$ and $\mathrm{SAI}_{\text {tree }}$ (4.0), values that are much lower than those reported by Nobel (1988). LAI values of

Table 2. Number, fresh weight and dry weight $\left({ }_{ \pm} \mathrm{SE}\right)$ of canopy and root components in 10-year-old Opuntia ficus-indica trees (n=6) cv. Gialla, trained to a globe.

\begin{tabular}{lcccc} 
& Number & $\begin{array}{c}\text { Fresh weight } \\
(\mathrm{kg})\end{array}$ & $\begin{array}{c}\text { Dry weight } \\
(\mathrm{kg})\end{array}$ \\
Current-year cladodes & & $217.7 \pm 14.3$ & $15.8 \pm 1.1$ & 5.0 \\
1-year-old cladodes & $224 \pm 17.1$ & $301.9 \pm 9.3$ & $28.5 \pm 1.6$ & 9.0 \\
\hline$\geq 2$-year-old cladodes & $219 \pm 12.7$ & $550.3 \pm 14.8$ & $60.9 \pm 1.6$ & 19.3 \\
Scaffold & $259 \pm 9.0$ & $288.9 \pm 8.6$ & $31.7 \pm 1.6$ & $123.1 \pm 6.6$ \\
Trunk & $88 \pm 8.5$ & $723.8 \pm 15.3$ & $55.0 \pm 1.8$ & 39.1 \\
Roots & - & $152.3 \pm 8.6$ & $315 \pm 14.3$ & 17.5 \\
\hline Total & - & $2234.9 \pm 70.9$ & 100 \\
\hline
\end{tabular}

Table 3. Number, specific dry weight, surface area, stem area index of photosynthetic active cladodes and scaffolds in trees ( $\mathrm{n}=6)$ of Opuntia ficus-indica cv. Gialla, trained to a globe.

\begin{tabular}{|c|c|c|c|c|c|c|}
\hline & $\begin{array}{l}\text { Cladodes } \\
\text { (n) }\end{array}$ & $\begin{array}{c}\text { Specific dry } \\
\text { weight } \\
\left(\mathrm{mg} \mathrm{dw} \mathrm{cm}^{-2}\right)\end{array}$ & $\begin{array}{c}\text { Cladode mean } \\
\text { surface area } \\
\left(\mathrm{cm}^{2}\right)\end{array}$ & $\begin{array}{c}\text { Canopy } \\
\text { surface area } \\
\left(\mathrm{m}^{2}\right)\end{array}$ & $\begin{array}{l}\text { SAI } \\
\text { tree }\end{array}$ & $\begin{array}{c}\text { SAI } \\
\text { orchard }\end{array}$ \\
\hline Current-year-cladodes & $231 \pm 13.7$ & $61.4 \pm 0.17$ & $1242.9 \pm 3.19$ & $28.7 \pm 1.77$ & $1.5 \pm 0.10$ & $1.0 \pm 0.06$ \\
\hline 1-year-old-cladodes & $219 \pm 12.7$ & $91.6 \pm 0.50$ & $1425.5 \pm 3.33$ & $31.2 \pm 1.85$ & $1.6 \pm 0.10$ & $1.0 \pm 0.06$ \\
\hline 2-year-old-cladodes & $109 \pm 9.0$ & $121.6 \pm 2.71$ & $1584.3 \pm 9.97$ & $17.2 \pm 1.44$ & $0.9 \pm 0.08$ & $0.6 \pm 0.03$ \\
\hline 3-4 year-old-cladodes & $150 \pm 7.0$ & $150.5 \pm 3.51$ & $1893.9 \pm 9.97$ & $28.3 \pm 1.32$ & $1.4 \pm 1.32$ & $0.9 \pm 0.05$ \\
\hline Scaffold & $88 \pm 8.5$ & $190.3 \pm 1.74$ & $1894.6 \pm 7.13$ & $16.7 \pm 1.21$ & $0.8 \pm 1.32$ & $0.6 \pm 0.02$ \\
\hline Total & $797 \pm 24.4$ & - & - & $122.1 \pm 3.09$ & $6.2 \pm 0.17$ & $4.1 \pm 0.10$ \\
\hline
\end{tabular}

SAI, stem area index. 
3.5, 5.4, 4.1 have been reported, respectively for orange (Liguori et al., 2009), peach (Caruso et al., 1999), apple (Forshey et al., 1983) optimal productions. Orchard yield $\left(20 \mathrm{t} \mathrm{ha}^{-1}\right)$ was very high (Inglese et al., 2002); however, we measured only 6.0 fruit $\mathrm{m}^{-2}$ of photosynthetic active surface area, and 14 fruit $\mathrm{m}^{-2}$ of 1-year-old cladodes that means no more than 2 fruit cladode ${ }^{-1}$. Indeed, only 114 out of 2191 -year-old cladodes bore fruit though a fertile cladode may support 6-7 fruit (Inglese $e t$ al., 1994) with no apparent reduction of their final size and weight. This suggests the need for a deeper knowledge on plant fertility and the development on new strategy to optimize orchard design and canopy architecture, i.e. 1-year-old cladode distribution within the canopy, with the ultimate goal of increasing SAI photosynthetically active components, and cladode fertility.

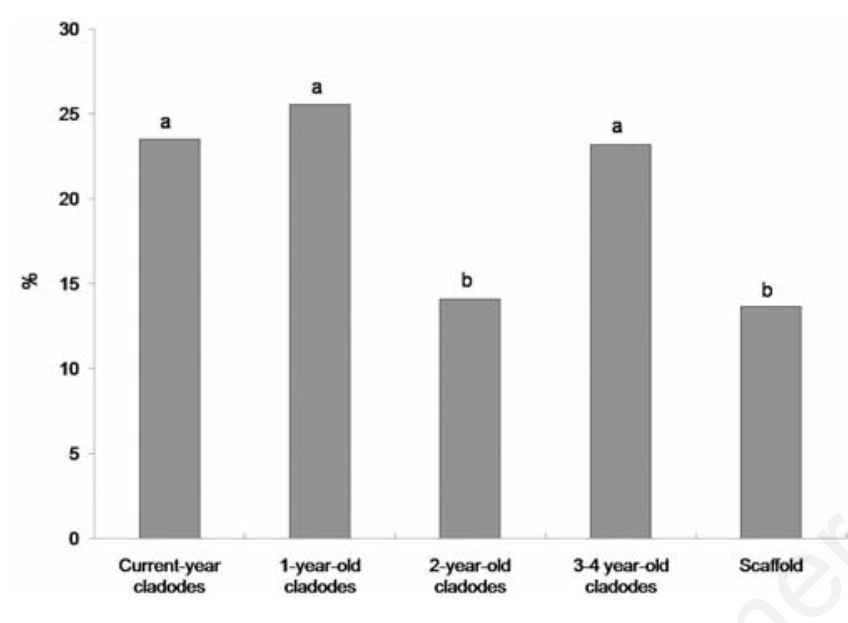

Figure 1. Percent of total surface area of cladodes partitioned by age in 10-year-old Opuntia ficus-indica trees $(\mathrm{n}=6) \mathrm{cv}$. Gialla. Different letters denote significant difference at $P \leq 0.05$ with Tukey's test.

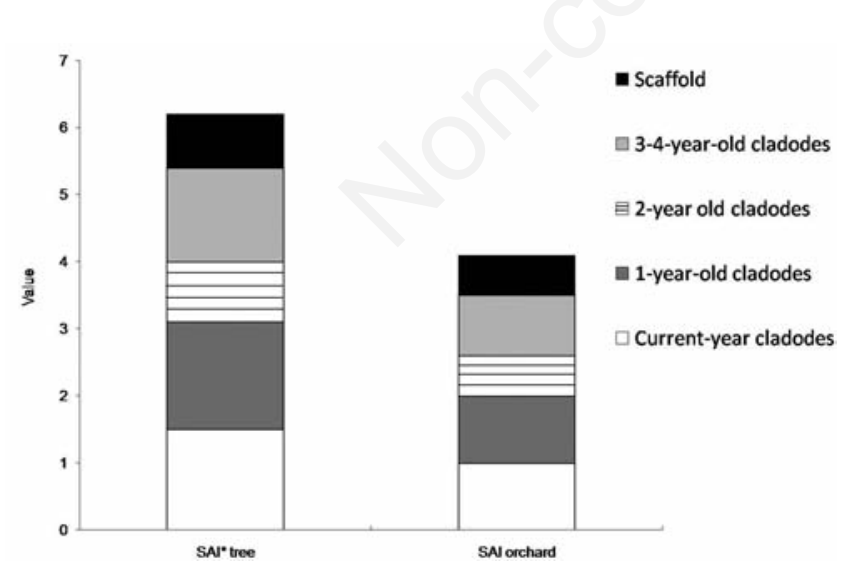

Figure 2. Relative contribution on stem area index (SAI) calculated on tree and orchard basis of current-year, 1-year-old, 2-yearold, 3-4-year-old cladodes and scaffold (non photosyntetically active) in 10-year-old Opuntia ficus-indica trees cv. Gialla.

\section{Conclusions}

Opuntia ficus-indica fruiting trees showed high productivity, both in terms of fruit crop yield and C fixed in the canopy. However, the fruit density in the canopy was relatively low and the harvest index was lower than $30 \%$, suggesting a possible further increase in yield with no reduction of fruit size. One of the major issues to be addressed is the reduction of large (35\%) portions of the canopy that show no photosynthesis and shade the active cladodes as well. This claims for new strategy in orchard design, plant architecture and pruning.

\section{References}

Acevedo E, Badilla I, Nobel PS, 1983. Diurnal acidity changes, and productivity of a cultivated cactus, Opuntia ficus-indica. Plant Physiol. 72:775-80

Barbera G, Carimi F, Inglese P, 1991. The reflowering of prickly pear Opuntia ficus-indica (L) Mill: influence of removal time and cladode load on yield and fruit ripening. Adv. Hort. Sci. 2:77-80.

Caruso T, Inglese P, Marra FP, Sottile F, 1999. Effect of planting system on productivity, dry matter partitioning and carbohydrate content in aboveground components of 'Flordaprince' peach trees. J. Am. Soc. Hort. Sci. 124:39-45.

Garcia de Cortazar VG, Nobel PS, 1992. Biomass and fruit productivity for the prickly pear cactus Opuntia ficus-indica (L.) Mill. J. Am. Soc. Hort. Sci. 117:558-62.

Forshey CG, Weires RW, Stanley BH, Seem RC, 1983. Dry weight partitioning of 'Mclntosh' apple trees. J. Amer. Soc. Hort. Sci. 108:149-54.

Inglese P, Israel AA, Nobel PS, 1994. Growth and $\mathrm{CO}_{2}$ uptake for cladodes and fruit of the Crassulacean acid metabolism species Opuntia ficusindica during fruit development. Physiol. Plantarum 91:708-14.

Inglese P, Barbera G, La Mantia T, 1999. Seasonal reproductive and vegetative growth patterns and resource allocation during cactus pear Opuntia ficus-indica (L.) Mill. Fruit growth. Hort. Sci. 34:69-72.

Inglese P, Gugliuzza G, La Mantia T, 2002. Alternate bearing and summer pruning of cactus pear. Acta Hort. 58:202-4.

Inglese P, Inglese G, Liguori G, 2012. Fruit productivity and carbon gain of Opuntia ficus-indica (L.) Mill. trees. Israel J. Plant Sci. 60:283-90.

Liguori G, Gugliuzza G, Inglese P, 2009. Evaluating carbon fluxes in orange orchards in relation to planting density. J. Agric. Sci. 147:637-45.

Liguori G, Inglese G, Pernice F, Sortino G, Inglese P, 2013. $\mathrm{CO}_{2}$ uptake of Opuntia ficus-indica (L.) Mill, whole trees and single cladodes, in relation to plant water status and cladode age. Ital. J. Agron. 8:14-20.

Nobel PS, 1988. Enviromental biology of agaves and cacti. Cambridge University Press, Cambridge, UK.

Pinos-Rodríguez JM, Velázquez JC, González SS, Aguirre JR, García JC, Álvarez G, Jasso Y, 2010. Effects of cladode age on biomass yield and nutritional value of intensively produced spineless cactus for ruminants. S. Afr. J. Anim. Sci. 40:245-50.

Tagliavini M, Panzacchi P, Ceccon C, Liguori G, Bertolla C, Meggio F, Tonon G, Corelli Grappadelli L, Celano G, Gucci R, Pitacco A, Inglese $\mathrm{P}, 2008$. Fluxes of carbon in Italian orchards. Page 90 in 1st Symp. on Horticulture in Europe -Book of Abstract, Vienna, Austria. 